ISSN 1411 - 013X

IQTISAD Journal of Islamic Economics Vol. 3, No. 1, Muharram 1423 H/Maret 2002

pp. 67-87

\title{
PENYESUAIAN TEORI AKUNTANSI SYARIAH: PERSPEKTIF AKUNTANSI SOSIAL DAN PERTANGGUNGJAWABAN
}

\author{
Muhamad \\ Sekolah Tinggi Ilmu Syariah Yogyakarta
}

\begin{abstract}
Assumption that accounting is a value free science and practice has been critized since 1970s. There is a very basic question that accounting is value free or not. Some fundamental concepts are now re-questioned, i.e: interest position, basic assumption or concept and its impact on practise, and also methodology. This paper discuss about Islamic perspective on accounting and practise, or known as shariah accounting. Shariah accounting based on the main Islamic source Al Qur'an and Hadist, both on its paradigm and practise. It has not only a social orientation but also a responsibility orientation. Shariah accounting will report social impact of an activity and a humanistic, emancipatoric, transcendental and theological responsibility. In Islamic terminology, shariah accounting is a zakah and amanah oriented.
\end{abstract}

\section{PENDAHULUAN}

Dewasa ini, nilai-nilai agama telah dijadikan pijakan dalam pengembangan dan pelaksanaan aktivitas bisnis, sehingga bisnis diharapkan tidak meninggalkan etika. Dalam tradisi Islam, seluruh etika yang dijadikan kerangka bisnis, dibangun atas dasar Syariah. Syariah merupakan pedoman yang digunakan oleh umat Islam untuk berperilaku dalam segala aspek kehidupan ${ }^{1}$ Bagi umat Islam, kegiatan bisnis (termasuk bisnis perbankan) tidak akan pernah terlepas dari ikatan etika Syariah.

Oleh karena itu, bukan hal yang berlebihan bila, misalnya, bank Islam beroperasi berdasarkan pada nilai etika Syariah. Bahkan secara formal bank Islam membentuk suatu badan khusus dalam organisasinya. Badan ini bertugas memberikan pandangan dasar-dasar etika (atau pengawasan) Syariah bagi manajemen dalam menjalankan operasi bank (termasuk pencatatan dan pelaporan

${ }^{1}$ Iwan Triyuwono, "Organisasi, Akuntansi, dan Spiritualisme Islam”, Makalah Stadium General Mahasiswa Syari'ah Banking Institute Yoyakarta, tanggal 28 September 1996, Hal. 10 akuntansinya). Badan tersebut dinamakan Dewan Pengawas Syariah yang berdiri secara tidak tergantung pada bagian bank lainnya (independent) di dalam organisasi bank. ${ }^{2}$

Dalam konteks pembangunan ekonomi umat, keberadaan dan kehadiran lembaga bisnis, seperti lembaga keuangan syariah adalah mutlak adanya. Sebab perbankan bertindak sebagai perantara (intermediary) antara unit penawaran (supply) dengan unit permintaan (demand). Disinilah diperlukan proses pencatatan dan pelaporan semua transaksi dan kegiatan muamalah yang dilakukan di unit bisnis. Oleh karena itu, diperlukan sistem akuntansi yang sesuai (relevan). Sehubungan dengan itu, perlu pula adanya proses akuntansi. Proses akuntansi ini tidak saja akan mempengaruhi perilaku manajemen, pemegang saham, karyawan, dan masyarakat sekelilingnya, tetapi juga organisasi yang bersangkutan. Namun demikian, ini bukan berarti bahwa bentuk organisasi adalah faktor satu-satunya yang dapat mempengaruhi bentuk akuntansi.

${ }^{2}$ Ibid, 1996, Hal. 11. 
Faktor-faktor lain seperti sistem ekonomi, sosial, politik, peraturan perundang-undangan, kultur, persepsi, dan nilai yang berlaku dalam masyarakat mempunyai pengaruh besar terhadap bentuk akuntansi. Hal ini membuktikan bahwa akuntansi adalah sebuah keutuhan (entitas/entity) informasi yang tidak bebas nilai.

Sehubungan dengan hal di atas, Baswir menyatakan bahwa: "munculnya kesan bahwa akuntansi juga memiliki kaitan dengan ideologi sulit untuk dielakkan, dan akuntansi seperti yang saat ini diajarkan pada jurusanjurusan akuntansi di Indonesia, ternyata sangat kuat dipengaruhi oleh kapitalisme. Pengaruh kapitalisme itu terutama tampak sangat nyata pada kuatnya pengaruh prinsip ekonomi kapitalistik dalam penyajian laporan pendapatannya.",

Dengan demikian, apabila suatu negara mengikuti Sistem Ekonomi Islam maka upaya yang harus dikembangkan adalah Sistem Akuntansi Islam (Syariah). Namun perlu disadari bahwa anggapan terhadap keberadaan akuntansi Syariah (Islam) masih banyak dipertanyakan orang. Lahirnya akuntansi Syariah adalah setelah adanya anggapan kurang yakin terhadap keberadaan akuntansi konvensional sebagai ilmu pengetahuan dan pelaksanaannya dalam kaitannya dengan persoalan nilai dalam akuntansi.

Anggapan tentang akuntansi sebagai ilmu pengetahuan dan praktik yang bebas dari nilai (value-free) pada akhir tahun 1970an sudah mulai digoyang keberadaannya. Anggapan tersebut sejak lama mendominasi sebagian besar akuntan dan para peneliti di bidang akuntansi. Keadaan semacam ini semakin kuat karena adanya kecenderungan perilaku masyarakat yang terbawa oleh arus era informasi dan globalisasi. Ciri utama dari era informasi dan globalisasi adalah

${ }^{3}$ Revrisond Baswir, "Akuntansi dan Ideologi", Kertas Kerja pada S minar Nasional Harteknas, Yogyakarta tanggal 27 Desember 1996, Hal. 9.

${ }^{4}$ Triyuwono Iwan, Opcit, 1996, Hal. 12. adanya kecenderungan untuk melakukan harmonisasi sesuatu. Hal ini berarti adanya kehendak untuk memberlakukan praktikpraktik tertentu, termasuk praktik akuntansi secara seragam.

Triyuwono menyatakan bahwa akuntansi syariah merupakan salah satu upaya mendekonstruksi akuntansi modern ke dalam bentuk humanis dan sarat nilai. ${ }^{5}$ Lebih rinci Triyuwono dan Gaffikin menyatakan, bahwa: "...The fundamenta laim of the shari'ate accounting knowledge is not only to reflect ethical reality in an "acurate" manner, but also to guide the creation of reality which is based on the Shari'ate values. This sort of reality is unique as it is the one which binds individuals to divine networks" (divine social laws) which also brings about self consciousness of the individuals to worship only God through obeying or living harmoniously with the divine networks. This means that the Shari'ate accounting knowledge consists of value which attempt to emancipate individuals from a false reality, that is the reality which may enslave the individuals or may make them far from their real nature as vicegerent of God on earth (khalifatullah fil ardh) whose duty is to disseminate mercy for all creatures in the form of worship. ${ }^{6}$ "

Fungsi manusia di muka bumi adalah sebagai khalifah. Oleh karena itu, seluruh upaya yang dilakukan oleh manusia harus mampu menjawab kebutuhan masyarakat atau harus berorientasi sosial. Demikian pula upaya kita untuk mengembangkan akuntansi syariah. Akuntansi harus berkembang dengan menjawab kebutuhan masyarakat. ${ }^{7}$ Lebih

\footnotetext{
${ }^{5}$ Ibid, 1996, Hal. 10.

${ }^{6}$ Iwan Triyuwono and M.J.R. Gaffikin, 1996, "Shari'ate Accounting: An Ethical Construction of Accounting Knowledge" The Fourth Critical Perspectives on Accounting Symposium, 26-28 April 1996, New York City, 1996, Hal. 20.

${ }^{7}$ Clark E. Chastain, "Accounting and Society: A Behavioral View," International Journal of Accounting, Education and Research, Vol. 8, No. 2 (Spring 1973), 1993, Hal. 1.
} 
lanjut Gilling menjelaskan situasi akuntansi yang intinya sebagai berikut:

"Dari suatu alat mekanis yang (dulunya) diterapkan pada kegiatan bisnis, akuntansi berkembang menjadi media yang sangat penting untuk mengungkapkan fakta-fakta penting tentang (keadaan) masyarakat modern yang serba kompleks dimana kita hidup. (Akhirnya) akuntansi merupakan upaya pencatatan dan pelaporan informasi yang digunakan oleh pemilik pengawasan, sebab dan pemegang saham, investor (sebagai alat) pihak-pihak tersebut tidak secara langsung mengetahui kondisi dan kegiatan perusahaan. ${ }^{8}$

Kutipan di atas bermakna bahwa tujuan dari akuntansi tidak lagi membuat pertanggungjawaban yang jelas bagi pemilik perusahaan tetapi juga untuk menjadikan perusahaan tetap hidup (survive). Di pihak lain akuntansi telah menjadi alat ukur untuk mengetahui keuntungan perusahaan yang berbeda dari keuntungan sosial. Sementara, Chastin menyatakan, bahwa "masyarakat mengharapkan agar perusahaan bertindak sebagai koordinator dalam menggunakan Sumber Daya Manusia (SDM), bahan, dan dana untuk menghasilkan barang dan jasa dan mendistribusikan hasilnya kepada para penyumbang modal". ${ }^{9}$ Namun, sampai saat ini belum dikembangkan metode pelaporan kemajuan masyarakat secara utuh dan sesuai dengan syariah.

Islam melalui al-Qur'an telah menggariskan bahwa konsep akuntansi yang harus diikuti oleh para pelaku bisnis atau pembuatan laporan akuntansi menekankan pada konsep pertanggungjawaban atau accountability, sebagaimana ditegaskan dalam Surat al-Baqarah ayat 282. Disamping itu, akuntansi Syariah harus berorientasi sosial. Hal ini berarti, bahwa akuntansi tidak hanya sebagai alat untuk menterjemahkan fenomena

${ }^{8}$ D.M. Gilling, "Accounting and Social Change," International Journal of Accounting, Education and Research, Vol. 1, No.2 (Spring 1976), 1996, Hal. 59. ${ }^{9}$ Clark E. Chastain, Opcit, 1993, Hal. 2. ekonomi dalam bentuk ukuran moneter tetapi juga sebagai suatu metode untuk menjelaskan tentang bagaimana fenomena ekonomi itu berjalan dalam masyarakat (Islam).

\section{RUMUSAN MASALAH}

Berdasarkan latar belakang masalah di atas, maka problematika tesis ini dirumuskan sebagai berikut:

- Bagaimanakah hakekat akuntansi syariah dilihat dari perspektif akuntansi sosial dan pertanggungjawaban?

- Apakah akuntansi itu merupakan suatu bentuk pengetahuan dan praktik yang banyak ditentukan oleh lingkungannya (non value-free), atau dengan kata lain, apakah akuntansi adalah "anak" yang lahir dari budaya setempat (lokal)?

\section{METODE PENELITIAN}

Upaya rasional, penentuan kebenaran hakikat dan eksistensi akuntansi syariah perlu diteliti dengan metode penelitian yang tepat. Ketepatan metode penelitian tersebut akan tercermin pada tahap-tahap penelitian yang dilalui.

\section{Tahap Penelitian}

Penelitian ini dilakukan untuk menemukan rasionalitas dan kebenaran hakikat, pengetahuan dan praktik akuntansi, maka kajian teori kritis akan digunakan, yang penerapannya dilakukan melalui dua tahapan, yaitu: tahap deskriptif dan tahap evaluatif/kritik. Kedua tahap kajian ini masing-masing menggunakan metode yang berbeda, sesuai dengan esensi permasalahan penelitian ini.

\section{Tahap Deskriptif}

Pada tahap reduksi penulis mengarahkan pada pokok-pokok masalah yang telah diajukan dengan menggunakan kerangka dasar filsafat ilmu. Berpijak dari filsafat ilmu inilah, maka kerangka bangun hakekat akuntansi syariah dapat dilihat dari sisi: ontologi; epistimologi, metodologi dan aksiologi, 
sehingga sasaran dan orientasi bangun akuntansi syariah dapat terwujud. Dimaksud dengan bangun akuntansi syariah tersebut diantaranya adalah bangun akuntansi yang merefleksikan dimensi sosial dan pertanggungjawaban.

Ontologi menyangkut tentang hakekat apa yang dikaji atau science of being qua being. ${ }^{10}$ Epistimologi adalah berkaitan dengan bagaimana cara ilmu pengetahuan melakukan pengkajian dan menyusun tubuh pengetahuannya atau studi filsafat yang membahas ruang lingkup dan batas-batas pengetahuan. ${ }^{11}$ Metodologi digunakan untuk menguji metode-metode yang digunakan atau yang akan digunakan untuk menghasilkan pengetahuan yang valid. ${ }^{12}$ Sementara aksiologi adalah tiang penyangga filsafat ilmu yang berkaitan dengan kegunaan ilmu yang telah tersusun itu dipergunakan atau theory of value. ${ }^{13}$

Berdasarkan tiga sisi tersebut selanjutnya dapat dilakukan analisis terhadap esensi ilmu pengetahuan. Walaupun harus disadari bahwa sebagai bahan untuk mengkaji Akuntansi Syariah (Islam) maka jalan terbaik yang ditempuh adalah mempelajari Akuntansi Barat yang sudah demikian mapan dan berkembang, bahkan telah dianut baik oleh masyarakat Barat maupun masyarakat muslim. $^{14}$

Suatu badan usaha/organisasi/lembaga baik yang bertujuan mencari laba maupun nirlaba (non-profit) membutuhkan informasi untuk proses pengambilan keptusan dan

\footnotetext{
${ }^{10}$ Ervin Laszlo, Introduction to System Philosophy. (New York: Science Publishers, Inc), 1971, Hal. 143.

${ }^{11}$ Dalam Imam Syafi' ie, "Konsep Ilmu Pengetahuan dalam al-Qur'an (Pendekatan Tafsir Tematik). Disertasi. (Yogyakarta: PPS. IAIN Sunan Kalijaga), 1998, Hal. .

${ }^{12}$ M.J.R. Gaffikin, Accounting Methodology and The Work of R.J. Chambers. (New York: Garland Publishing, Inc.), 1998, Hal. 2.

${ }^{13}$ Dagobert D. Runes, Dictionary of Philosophy. (New Jersey: Littlefield, Adams \& Co.), 1976, Hal. 32.

${ }^{14}$ Sofyan Syafri Harahap, Akuntansi Islam, (Jakarta Bumi Aksara), 1997, Hal. 24.
}

pengembangan perusahaan. Pada sisi inilah akuntansi berperan. Akuntansi merupakan bagian yang tidak terpisahkan dari suatu gugusan tugas manajemen dalam mencapai tujuannya. Akuntansi akan memberikan informasi yang sangat dibutuhkan manajemen dalam melaksanakan fungsi-fungsinya, yaitu: Perencanaan; Pengorganisasian; Pengarahan; dan Pengawasan. ${ }^{15}$

Fungsi-fungsi tersebut merupakan fenomena yang akan menjadi kajian keilmuan, terutama yang berkaitan dengan hakekat dari sudut pandang syariah Islam. Kesesuaian antara fenomena yang terjadi dengan apa yang telah digariskan dalam sistem-Nya, yaitu ayat-ayat al-Qur'an. Dari sinilah akan dapat ditemukan hakikat ilmu yang sebenarnya, baik dari sisi pengertian, cara memperoleh dan kegunaan bagi masyatakat Islam pada khususnya dan masyarakat dunia pada umumnya. Hadjisarosa menyatakan "sesuatu (ekonomi/akuntansi) menurut pengertian yang umum akan memperoleh predikat syariah setelah dikenali secara benar dan utuh, dengan catatan, benar dan utuh menurut Hukum-hukum KetetapanNya (sunatullah). ${ }^{16}$

\section{Tahap Evaluatif}

Metode yang digunakan pada tahap evaluatif adalah metode analitik kritis-rasional. Metode ini diterapkan mengingat pada tahap ini dilakukan upaya membandingkan konsep Akuntansi Barat dengan konsep Akuntansi Syariah. Seperti halnya dalam upaya mengkaji atau membangun teori sosial, termasuk teori akuntansi, maka proses berfikir analisis: kritis dan rasional sangat dituntut. Dalam

\footnotetext{
${ }^{15}$ Ibid, Hal. 25.

${ }^{16}$ Hadjisarosa, Poernomosidi, 1997, "Naskah Ringkas mengenai: Mengenali Ekonomi Syariah dengan Menempuh Pendekatan Sistem (Bagian Pertama) dalam rangka Penyelenggaraan Ekonomi Syariah yang Semestinya Berlangsung di Indonesia (Bagian Kedua)", Makalah Kursus Singkat dan Lokakarya Ekonomi Islam II Sekolah Tinggi Ilmu Syariah, Yogyakarta, tanggal 18 - 21 Agustus 1997, Hal. 4.
} 
penelitian akuntansi, pendekatan kritis (critical studies) merupakan salah satu pendekatan yang disarankan untuk diterapkan. Banyak istilah yang disarankan, sebagaimana diungkapkan oleh Lodh, bahwa: "There are many labels for 'critical accounting' or 'critical studies in accounting research'.17 Sebagai contoh, MacIntosh menggunakan istilah critical accounting movement ${ }^{18}$, Cooper \& Hopper menggunakan istilah critical accounting ${ }^{19}$ walaupun sebelumnya mereka menggunakan istilah critical studies. Sementara Neimark and Tinker memakai istilah critical accounting literature ${ }^{20}$. Kemudian Laughlin menggunakan istilah critical theory ${ }^{21}$ yang digunakan untuk memaknai istilah critical social theory khususnya teori kritis yang berasal dari German.

Istilah-istilah yang disampaikan di atas, mengandung perbedaan terminologi jika akan diterapkan pada kajian teori akuntansi dan penelitian akuntansi. Critical studies is used as the general umbrella concept of this research school, it is possible to question the ultimate concern of critical studies in accounting. $^{22}$ Jenis inilah yang menentang epistimologi aliran positivistik, sehingga Cooper dan Hopper beragumen, bahwa: “... it is a concern with accessing the significance of accounting as a set of everyday practices

\footnotetext{
${ }^{17}$ Sudhir C. Lodh, "Critical Studies in Accounting Research, Rationality and Habermas: A Methodological Reflection", Paper to be Presented at the Fourth CPA Conference. New York City, 26-28 April 1996, Hal. 3.

${ }^{18}$ N.B. MacIntosh, "Deconstructionism and Critical Accounting". Paper Presented at The Second Interdiciplinary Perspectives on Accounting Conference at the University of Manchester (July 1988)

${ }^{19}$ dalam Sudhir C. Lodh, Opcit, 1996, Hal. 3.

${ }^{20}$ M. Neimark and Tinker, The Social Construction of Management Control System. New York: PrenticeHall. 1996

${ }^{21}$ R. CLaughlin, Accounting System in Organization Theory: A Case for Critical Theory, Accounting, Organization and Society, 1987, Hal. 235.

${ }^{22}$ Sudhir C. Lodh, Loc.Cit, 1996, Hal. 3.
}

and as a series of theorical discourses central to studies in accounting". ${ }^{23}$

Akan tetapi apabila peneliti akan memahami praktek dan teori akuntansi, maka istilah yang digunakan adalah critical studies in accounting. ${ }^{24}$ Menurut Laughlin, Hopper dan Miller menyatakan bahwa critical study ini digunakan: "to identify the document the role that sectional interests play in accounting". ${ }^{25}$ Lebih jauh dalam mengantarkan antologi critical papers, Cooper dan Hopper menyatakan: “...critical accounting arose both as an expression of attempts by scholars within accounting to apply fresh, typically nonfunctionalist, theoritical insights into the effects of accounting within organisations and society". ${ }^{26}$

Sehubungan dengan perkembangan sistem ekonomi baru, yaitu sistem ekonomi Islam, tentu saja kondisi ini menuntut relevansi seluruh instrumen, model, sistem dan paradigma akuntansi. Dengan kata lain, kondisi ini harus dibarengi dengan munculnya keterbukaan dan kesadaran para ilmuwan untuk menemukan dan mengembangan ilmu baru yang sesuai dengan disiplin yang ada. Oleh karena itu, Cooper dan Hopper menyatakan bahwa: “... critical accounting is critical of convetional accounting theory and practice and, through critical social science theory, it seeks to explain how the current state of accounting has come about". ${ }^{27}$

Pernyataan ini menandakan betapa pentingkan critical theory dalam rangka membangun suatu teori baru yang sesuai (relevan) dengan perkembangan masyarakat. Bagaimana kerangka kerja yang akan

\footnotetext{
${ }^{23}$ D.J. Cooper dan T.M. Hopper, "Critical Studies in Accounting”, Accounting Organization and Society. (New York: Prentice-Hall International, Inc.), 1987, Hal. 411.

${ }^{24}$ Sudhir C. Lodh, Op.Cit, 1996, Hal. 3.

${ }^{25}$ R.C. Laughlin, T. Hopper \& P. Miller. 1989. "Contextual Studies of Accounting and Auditing: An Introduction", Accounting, Auditing and Accountability. Journal, 1989, Hal. 4.

${ }^{26}$ D.J. Cooper dan T.M. Hopper, Loc.Cit., 1990, Hal. 1

${ }^{27}$ Ibid, 1990, Hal. 2
} 
ditempuh apabila kita menggunakan pendekatan critical theory? Pada tataran yang lebib luas, menurut Lodh disarankan, bahwa: "... an accounting researcher can ask: what, how and why accounting rationale has become purposive, is being used, is to be used, and what are the means for doing so in a particular context? ${ }^{28}$

Melalui pendekatan critical theory kita akan melihat suatu teori itu bukan saja terletak pada upaya menempatkan ideologi sebagai 'bentuk pemikiran' akan tetapi juga akan mencoba mengkaji tentang bagaimana kondisi sosial, seperti sistem akuntansi yang dikembangkan oleh kaum kapitalis, terpenuhinya kepuasan kebutuhan hidup, dan kebebasan diri dari kondisi sosial masyarakat yang rentan. ${ }^{29}$

Berdasarkan uraian di atas, maka melalui pendekatan critical theory ini akan mampu menemukan kerangka rasional hakikat dan penerapan teori akuntansi yang lebih sesuai dengan budaya lokal Islam, yang sarat dengan nilai. Dengan kata lain, pendekatan yang diterapkan dalam penelitian ini harus dimapankan sebagai: "a process which can be used for analysing and changing the nature of any accounting system, and its social context, of any particular organisation". 30 Artinya, suatu proses yang dapat digunakan untuk menganalisis dan mengubah hakikat sistem akuntansi dalam hubungannya dengan kondisi sosial atau organisasi tertentu.

\section{Metode Pengumpulan Data}

Sesuai dengan pendekatan yang digunakan dalam penelitian ini, maka data yang digunakan adalah berupa pernyataanpernyataan ahli yang relevan. Dengan

\footnotetext{
${ }^{28}$ Sudhir C. Lodh, Loc.Cit, 1996, Hal. 7.

${ }^{29} \mathrm{M}$. Alvesson, Organization Theory and Technocrative Consciousness: Rationality, Ideology and Quality of Work. (New York: De Gruyter), 1987, Hal. 150.

${ }^{30}$ R.C. Laughlin, Accounting System in Organization Theory: A Case for Critical Theory, Accounting, Organization and Society. 1987, Hal. 489.
}

demikian teknik pengambilan sampel data adalah dengan purposive sampling/data, yang selanjutnya didukung dengan teknik analisis isi (content analysis). Teknik ini menurut Bogdan dan Biklen (1982) yang dikutip Syafi'ie dimaksudkan untuk pengambilan sampel internal (internal sampling). ${ }^{31}$ Internal sampling yaitu keputusan yang diambil, begitu peneliti memiliki suatu pikiran umum tentang jumlah dokumen serta macamnya yang akan dikaji, dengan siapa akan berbicara, dan kapan akan melakukan observasi.

Penggalian data primer mula-mula dilakukan dengan mengumpulkan ayat-ayat yang berkaitan dengan istilah perhitungan (hisab), keseimbangan, pertanggungjawaban, kemudian membuat outline dalam rangka menentukan ayat-ayat yang secara langsung berkaitan dengan ayat-ayat yang tidak secara langsung mengungkap tentang hisab, yang dalam penggaliannya menggunakan teknik dokumentasi murni. Sedangkan untuk mengumpulkan data sekunder dilakukan dengan mencari pokok-pokok pikiran yang ditulis oleh para pemikir atau ilmuwan yang telah ditulis dalam buku-buku terutama yang berkaitan dengan tema sentral yang telah diajukan, dalam rangka menemukan esensi tentang konsep akuntansi.

\section{Teknik dan Model Analisis}

Dalam penelitian kualitatif, pada tahap analisis setidak-tidaknya ada tiga komponen pokok yang harus disadari oleh peneliti, yaitu: data reduction, data display dan conclusion drawing (Miles \& Huberman, 1984; Sutopo, 1988). ${ }^{32}$ Tiga komponen tersebut saling berhubungan dan saling mendukung. Sehubungan dengan permasalahan akuntansi maka Gaffikin menyarankan empat tahapan yang harus dilalui oleh peneliti dalam menerapkan metodologi analisis. Keempat

\footnotetext{
${ }^{31}$ Imam Syafi' ie, Loc.Cit, 1998, Hal. 26.

${ }^{32}$ Ibid, 1998, Hal. 28.
} 
tahapan tersebut adalah: Logical, Environmental, Ideological dan Linguistic. ${ }^{33}$ Masing-masing tahapan tersebut saling berkaitan erat satu dengan yang lain. Oleh karena itu, keberhasilan konstruksi teori ini akan menemukan kecocokan kriteria pada semua bidang.

\section{HISAB, MUHASABAH DAN AKUNTANSI}

Syariah Islam adalah syari'at yang memberikan perhatian besar terhadap masalah hisab. Hisab adalah salah satu proses perhitungan amal selama hidup manusia di dunia oleh Allah. Sebagai khalifah, manusia diberikan amanah oleh Allah untuk mengelola bumi yang kemudian hasilnya dipertanggungjawabkan kepadaNya. Oleh karena itu, setiap manusia dalam hidupnya harus selalu dalam keadaan amanah, jujur dan komitmen tinggi terhadap janji yang telah diucapkan kepada Allah. Hal demikian ini merupakan bagian dari perilaku manusia yang Islami. Sehubungan dengan ini, Ghamidi (1997) mengatakan bahwa: "perilaku yang Islami, adalah perilaku yang pelakunya, selalu merasakan adanya pengawasan oleh Allah baik dalam keadaan tersembunyi maupun terlihat orang dan selalu melakukan muhasaba (menghitung-hitung atau mengevaluasi) diri, terhadap kaum Muslimin maupun terhadap yang lain, merupakan jalan dakwah kepada Islam yang terbaik."34

Oleh karena itu, kaum Muslimin harus kembali kepada Allah, mengoreksi diri mereka, menerapkan perilaku Islami dalam seluruh segi kehidupan, senantiasa jujur, iman dan qana'ah, agar kemuliaan dapat diraih kembali.

Berkaitan dengan kata muhasaba di atas, menurut Atiya dinyatakan, bahwa kata Arab

\footnotetext{
${ }^{33}$ M.J.R. Gaffikin, Accounting Methodology and The Work of R.J. Chambers. (New York: Garland Publishing, Inc.), 1989, Hal. 119.

${ }^{34}$ Mahdi bin Ibrahim bin Muhammad Mubjir, Amanah dalam Manajemen, Terjemahan Rahmad Abbas. (Jakarta: Pustaka al-Kautsar), 1997, Hal. 11.
}

yang berarti akuntansi adalah muhasabah (hisab). Kata ini muncul 48 kali dalam alQur'an. ${ }^{35}$ Sementara Muhammad Khir yang dikutip oleh Harahap disebutkan bahwa "Istilah hisab ditemukan 109 kali dalam alQur'an. ${ }^{36}$ Akar kata muhasabah adalah h.s.b dengan bentuk verbalnya hasaba dan bentuk lainnya yahsaba yang berarti mengitung (to compute) atau mengukur (to measure). Lebih jauh perubahan kata hisab menjadi muhasaba adalah sebagai berikut AlMuhasaba berasal dari perubahan kata "alhisab", yaitu perhitungan. Dari segi bahasa, munculnya kata al-muhasabah terjadi karena adanya perubahan isim, yaitu hisab/hisaban atau hasaba sebagai isim masdar termasuk fiil madli, kemudian yuhasibu sebagai isim masdar mim termasuk dalam fiil mudhari'.

Penggunaan kata hisab akan mengalami perubahan sesuai dengan kontek dan bentuk kalimat. Sehingga hisab akan berubah menjadi hasaba, jika kalimat yang dibentuk berarti "selesaikan tanggung jawab" atau "agar netral". Kemudian akan berubah menjadi tahasaba yang berarti "menjaga" atau "mencoba mendapatkan." Juga dapat berubah menjadi ihtisaba yang berarti "mengharapkan pahala di akhirat dengan diterimanya kitab seseorang dari Tuhan", juga berarti "menjadikannya perhatian" atau "mempertanggung jawabkannya". 37 Akhirnya dalam perkembangan selanjutnya, peristilahan kata bahasa Inggris berkembang secara etimologis, istilah Arab justru berkembang secara fonetis (suara), kata muhasabah (akuntansi) berkaitan dengan ihtisab dan citranya dikaitkan dengan pencatatan perbuatan seseorang secara terus menerus sampai pada pengadilan akhirat dan melalui

\footnotetext{
${ }^{35}$ M.K. 'Atiya, Accounting of the Company and the Bank for the Islamic Organization (Muhasaba Sharikat wa Musarif al-Mizan al-Islami), (Alexandria: DaralJamiat al-Misliya), 1984, Hal. 32.

${ }^{36}$ Sofyan Syafri Harahap, Akuntansi Islam, (Jakarta : Bumi Aksara), 1997, Hal. 276

${ }^{37}$ Ibid, Hal. 276-278
} 
timbangan (mizan) sebagai alat dan Tuhan sebagai akuntan.

Istilah lain yang memiliki makna sama dengan kata muhasaba adalah al-Hisba, namun kata al-hisbah menunjuk pada penerapan atau operasi suatu lembaga. Sehubungan dengan itu, Taymiyah menyebutnya, bahwa "al-Hisbah adalah lembaga publik yang telah ada pada masyarakat Islam sejak awal periode Islam sampai masa pendudukan Barat". ${ }^{38}$ Personil yang mengelola lembaga Hisba disebut muhtasib. Kegiatan lembaga ini mencakup tugas yang luas, yaitu mulai dari hal-hal yang bersifat ekonomi sampai pada yang bersifat etika.

Uraian di atas, menunjukkan bahwa kata hisab atau muhasaba dan pelaku muhasaba atau muhtasib adalah kata dan fungsi yang berkaitan dengan upaya untuk menghitung, mengukur atau mengendalikan seluruh aktivitas manusia selama hidup di dunia untuk dapat dipertanggungjawabkan di akhirat. Dengan demikian, muhtasib memiliki tugas yang sangat luas, dari pengawasan harta, yang menyangkut kepentingan sosial sampai pada pemeriksaan atas transaksi bisnis perusahaan.

Sebagaimana diuraikan di atas, bahwa di dalam al-Qur'an banyak ditemukan ayat yang menggunakan kata hisab yang dikaitkan dengan sifat dan fungsi hisab dari Allah kepada perbuatan manusia. Ayat-ayat inilah yang dijadikan nash tentang perhitungan amal perbuatan manusia selama hidup di dunia untuk dipertanggung-jawabkan di akhirat.

Ayat-ayat al-Qur'an yang berkaitan dengan masalah hisab, pada intinya adalah mengandung nilai-nilai yang dapat diterapkan dalam pelaksanaan akuntansi syariah. Dengan demikian, apabila keinginan kita hendak membangun suatu teori tentang akuntansi syariah, maka tidak dapat dilepaskan dari konsep dasar al-Qur'an tentang sesuatu teori. Dengan kata lain, nilai-nilai al-Qur'an harus

${ }^{38}$ Ibn. Taymiya, Public Duties in Islam: The Institution of the Hisba. London: Islamic Foundation, 1982, Hal. 2. dijadikan prinsip-prinsip dalam aplikasi akuntansi.

Kaitannya dengan penerapan akuntansi (muhasabah) atau pencatatan seluruh transaksi yang dilakukan selama bermuamalah, maka al-Qur'an memberikan rambu-rambu prinsip umum yang harus diikuti dalam bermuamalah. Prinsip-prinsip umum ini secara tegas dinyatakan dalam firman Allah, yang artinya sebagai berikut: "Hai orang-orang yang beriman, apabila kamu ber-muamalah tidak secara tunai untuk waktu yang ditentukan hendaklah seorang penulis di antara kamu menulisnya dengan benar. Dan jangnlah penulis enggan menuliskannya sebagaimana Allah telah mengajarkannya, maka hendaklah ia menulis, dan hendaklah orang berutang itu mengimlakkan apa yang ditulis itu, dan hendaklah ia bertaqwa kepada Allah Tuhannya, dan janganlah ia mengurangi sedikit pun daripada utangnya. Jika yang berutang itu orang yang lemah akal atau lemah keadaannya atau dia sendiri tidak mampu mengimlakkan, maka hendaklah wakilnya mengimlakkan dengan jujur dan persaksikanlah dengan dua orang saksi dari orang laki-laki di antara kamu ...,39

Terjemahan ayat tersebut di atas secara tegas Allah mengajarkan kepada manusia, bahwa apabila manusia melakukan kegiatan muamalah tidak secara tunai untuk waktu yang ditentukan, maka ia harus melakukan pencatatan. Kegiatan muamalah --dalam kerangka bisnis --memiliki makna "berutang piutang". Utang piutang pada intinya adalah berhubungan langsung dengan transaksi dagang. Disamping itu juga memiliki makna pinjaman kepada pihak lain apakah itu kepada perorangan maupun lembaga. Dalam kontek inilah al-Qur'an mengajarkan agar seluruh transaksi pinjam meminjam atau jual beli dilakukan penulisan transaksinya. Jika demikian maka akuntansi merupakan hal

\footnotetext{
${ }^{39}$ QS. Al-Baqarah (2): 282.
} 
penting dalam setiap transaksi perdagangan atau perusahaan.

Lebih-lebih lagi, proses perdagangan atau transaksi di masa sekarang telah mengalami pergeseran. Artinya, budaya transaksi dengan sistem kredit saat ini banyak di lakukan di samping adanya transaksi perdagangan secara kontan (tunai). Dengan demikian, proses pencatatannya harus dilakukan untuk transaksi kredit maupun tunai. Oleh karena itu, setiap transaksi dalam berniaga seharusnya ditulis secara baik dan benar. Sebab hal demikian dapat menjadi informasi penting dalam melakukan aktivitas niaga pada masamasa yang akan datang. Dengan melakukan penulisan terhadap semua transaksi, peminjam ataupun penjual akan lebih mudah mempertanggungjawabkan niaganya. Hal inilah yang menjadi inti dari ayat 282 QS. Al-Baqarah tersebut di atas. Dengan demikian, mengacu pada uraian di atas, maka secara ringkas dapat dirumuskan prinsip umum akuntansi syariah sebagai berikut:

- Keadilan

- Kebenaran

- Pertanggungjawaban

Berdasarkan tiga prinsip umum tersebut dan didukung dengan bentuk-bentuk praktis hisab yang tercantum dalam tiga puluh ayat di atas -yang akan dikenakan Allah kepada umat manusia-, maka selanjutnya dapat ditemukan prinsip-prinsip khusus dalam akuntansi syariah. Oleh karenanya nilai keadilan, kebenaran dan pertanggungjawaban pencatatan transaksi dapat terwujud apabila pelaporan akuntansi dilakukan dengan: benar; cepat; terang, jelas, tegas dan informatif; menyeluruh; ditujukan kepada semua pihak; terperinci dan teliti; tidak terdapat unsur manipulasi; dan dilakukan secara kontinyu.

\section{PENYESUAIAN}

\section{TEORI AKUNTANSI SYARIAH}

Pembicaraan akuntansi syariah (Islam), akhir-akhir ini semakin sering kita dengar, baik di dalam negeri maupun di luar negeri, walaupun keberadaan akuntansi syariah itu sendiri -seperti halnya dengan keberadaan Sistem Ekonomi Islam- masih dipertanyakan. Pembicaraan semacam itu muncul karena ilmu akuntansi yang dipelajari sampai saat ini masih tertuju dan merujuk pada sistem akuntansi Barat, yang didalamnya mengandung persoalan. Beberapa diantaranya adalah (1) persoalan kepemihakan, (2) asumsi atau basic concept, (3) efek dari persoalan basic concept tentu saja merembes ketingkat standar, atau bahkan metode akuntansi yang dipilih. ${ }^{40}$ Berangkat dari tiga persoalan dasar tersebut, maka semua asumsi, postulat, kaidah, dan prinsip-prinsip dalam akuntansi Barat dapat diterapkan untuk lembaga-lembaga atau perusahaan yang menegakkan nilainilai Islam. Oleh karena itu, perlu dirancang atau dibangun sistem, format akuntansi yang menegakkan nilai-nilai Islam.

Sesuai dengan topik ini, maka pembahasannya terfokus pada topik-topik sebagai berikut: Teori Akuntansi Syariah; dan Praktek Akuntansi Syariah, yang di dalamnya dibahas tentang refleksi akuntansi sosial dan pertanggungjawaban, dengan uraian sebagai berikut:

\section{Teori Akuntansi Syariah}

Ada suatu perubahan luar biasa dalam bidang ilmu akuntansi untuk beberapa dekade belakangan ini. Sebelum tahun 1970-an ada anggapan tentang akuntansi sebagai ilmu pengetahuan dan praktek yang bebas dari nilai (value-free) sudah mulai digoyang keberadaannya. Anggapan tersebut sejak lama mendominasi sebagian besar akuntan dan para peneliti di bidang akuntansi. Keadaan semacam ini semakin kuat karena adanya kecenderungan perilaku masyarakat yang terbawa oleh arus era informasi dan globalisasi.

\footnotetext{
${ }^{40}$ M. Akhyar Adnan, "(Teknologi) Akuntansi Syariah", Kertas Kerja Seminar Nasional Hari Teknologi Nasional, Yogyakarta. Radison, 1996.
} 
Pada era informasi dan globalisasi dalam bidang akuntansi ada upaya harmonisasi praktek-praktek akuntansi. Hal ini berarti ada kehendak untuk memberlakukan praktekpraktek akuntansi secara seragam seluruh dunia. Dengan kata lain, nilai-nilai lokal praktek akuntansi -yang mungkin sangat berbeda dengan praktek dunia internasional -sedapat mungkin dieliminasi karena keberagaman praktek akuntansi di setiap negara dianggap menyulitkan dalam menafsirkan laporan keuangan, atau praktek akuntansi yang beragam itu tidak dapat diperbandingan (uncomparable).

Kasus ini mengundang reaksi banyak kalangan, sehingga muncullah pandanganpandangan yang bersifat pro dan kontra. Mereka yang berpandangan kontra mengecam bahwa tindakan untuk melakukan harmonisasi merupakan tindakan pelecehan terhadap nilai-nilai lokal. Mereka justru melihat bahwa sebetulnya akuntansi adalah suatu bentuk pengetahuan dan praktek yang banyak ditentukan lingkungannya (non value-free). Bahkan ada yang mengatakan akuntansi adalah "anak" yang lahir dari budaya setempat (lokal).

Pandangan kedua, memang secara eksplisit menolak pandangan pertama yang bersifat fungsionalis dan positivistik, kalau ditelusuri ke belakang akar pemikiranya berasal dari August Comte. Pemikiran ini memiliki sifat reduksionis, yaitu menghilangkan kandungan nilai yang seharusnya terkandung dalam ilmu pengetahuan dan praktek akuntansi. Keringnya nilai ini menyebabkan masyarakat bisnis, ketidakseimbangan tatanan sosial, dan kerusakan lingkungan terjadi.

Berpijak dari kasus di atas, usaha untuk mencari bentuk akuntansi yang berwajah humanis, emansipatori, transendental, dan teleologikal merupakan upaya yang niscaya. Timbul pertanyaan, upaya apa yang harus dilakukan? Upaya ini secara filosofis dan metodologis dapat dilakukan dengan menggunakan meta perspektif, yaitu suatu pandangan yang berusaha berada di atas perspektif-perspektif yang ada. Karena dengan cara ini pandangan-pandangan filosofis, seperti pandangan tentang hakekat manusia dan masyarakat, ontologi, epistimologi, aksiologi dan metodologi, menjadi lebih luas dan utuh, sehingga formulasi pengetahuan dan praktek akuntansi menjadi lebih humanis dan sarat dengan nilai.

Akuntansi syariah, menurut Iwan Triyuwono dan Gaffikin dikatakan, merupakan salah satu upaya mendekontruksi akuntansi modern ke dalam bentuk yang humanis dan sarat nilai. Tujuan diciptakannya akuntansi syariah adalah terciptanya peradaban bisnis dengan wawasan humanis, emansipatoris, transendental, dan teleologikal. ${ }^{41}$ Konsekuensi ontologis upaya ini adalah bahwa akuntan secara kritis harus mampu membebaskan manusia dari ikatan realitas peradaban, beserta jaringan-jaringan kuasanya, kemudian memberikan atau menciptakan realitas alternatif dengan seperangkat jaringanjaringan kuasa Ilahi yang mengikat manusia dalam hidup sehari-hari (ontologi tauhid).

Dengan cara demikian, realitas alternatif diharapkan akan dapat membangkitkan kesadaran diri secara penuh akan kepatuhan dan ketundukan seseorang kepada kuasa Allah. Dengan kesadaran diri tersebut, ia akan selalu merasakan kehadiran Tuhan dalam dimensi waktu dan tempat dimana ia berada. Dengan demikian, melalui akuntansi syariah, realitas sosial akan dirancang dan dibangun melalui muatan nilai tauhid dan ketundukan pada jaringan-jaringan kuasa Ilahi. Kesemuanya itu dilakukan dengan perspektif khalifatullah fil ardh. Perspektif ini berarti suatu cara pandang yang sadar akan hakikat diri manusia dan tanggung jawab kelak di kemudian hari di hadapan Allah SWT.

\footnotetext{
${ }^{41}$ Iwan Triyuwono and M.J.R. Gaffikin, "Shari'ate Accounting: An Ethical Construction of Accounting Knowledge" The Fourth Critical Perspectives on Accounting Symposium, 26-28 April 1996, New York City, Hal. 6
} 
Akuntansi syariah pada intinya akuntansi yang akan dinilai kembali dari sudut pandangan Islam. Kecenderungan lahirnya akuntansi syariah adalah sangat baru dan para ahli akuntansi syariah belum secara jelas membuat tujuannya. Hal ini dapat menjadi suatu kasus jika diganti istilah ekonomi dunia ke akuntansi sebagaimana dikatakan oleh Baqir as-Sadr, bahwa "Ekonomi Islam ... bukanlah suatu pelajaran tetapi suatu teori .... Teori artinya metode dan alat belajar untuk menafsirkan". ${ }^{42}$

Oleh karena itu, akuntansi syariah adalah teori yang menjelaskan bagaimana mengalokasikan sumber-sumber yang ada secara adil bukan pelajaran tentang bagaimana akuntansi itu ada. Sehubungan dengan ini Shahata menjelaskan kemungkinan keberadaan akuntansi syariah sebagai berikut: "Postulat, standar, penjelasan dan prinsip akuntansi yang menggabarkan semua hal ... karenanya secara teoritis akuntansi memiliki konsep, prinsip, dan tujuan Islam dan semua ini secara serentak berjalan bersama bidang ekonomi, sosial, politik, ideologi, etika yang dimiliki Islam, kehidupan Islam dan keadilan dan hukum Islam. Dan Islam adalah suatu program yang memiliki bidangbidang ekonomi, sosial, politik, ideologi, manajemen, akuntansi, dan lain-lain. Kesemua ini adalah satu paket yang tak bisa dipisah., 43

Shahata menjelaskan maksud tersebut dalam rangka mempublisasi akuntansi Islam dalam bentuk definisi atau penyataan sebagai berikut: "Kita ingin menunjukkan aspek Islam dari akuntansi yang bersumber hukum hanya dari prinsip Islam, standar yang unik, tujuannya, prinsip atau hal-hal

\footnotetext{
${ }^{42}$ M. Baqir As-Sadr,. Islamic Economic. Translated : Toshio Kuroda (Isuramu Keizaron). (Neigata: The Institute of Middle Easter Studies, International University of Japan), 1986, Hal. 136.

${ }^{43}$ Shauqi Ismail Shahata, Financial Accounting from the Islamic Point of View, (Cairo: Alzahra al-A'lam alA'rabi), 1987, Hal. 9.
}

yang tercantum dalam Qur'an dan Sunnah, tetapi dari rencana sekarang dan masa depan dan sifat akuntansi yang dapat diambil dari pandangan aspek ini sebagai suatu yang unik dan dasar dari akuntansi." ${ }^{44}$

Dalam mencari bentuk akuntansi syariah, harus berangkat dari suatu asumsi bahwa akuntansi adalah sebuah entitas yang mempunyai dua arah kekuatan. Kekuatan pertama adalah bahwa akuntansi adalah sesuatu yang dibentuk oleh lingkungannya. Kekuatan kedua adalah bahwa akuntansi adalah sesuatu yang memiliki kekuatan untuk mempengaruhi lingkungannya, termasuk perilaku manusia yang menggunakan informasi akuntansi. Jika demikian, maka usaha yang harus dilakukan oleh para akuntan adalah bagaimana mereka dapat menciptakan sebuah bentuk akuntansi yang dapat mengarahkan perilaku manusia ke arah perilaku yang etis dan ke arah terbentuknya peradaban bisnis yang ideal. Menurut Triyuwono dikatakan bahwa bisnis yang ideal yaitu peradaban bisnis dengan nilai humanis, emansipatoris, transendental, dan teologikal. ${ }^{45}$

Sesuai dengan sifat bisnis tersebut, maka akuntansi syariah juga harus memiliki sifat humanis, emansipatoris, transendental, dan teologikal. Lebih jauh Triyuwono menguraikan sifat-sifat tersebut sebagai berikut. Nilai humanis akuntansi syariah adalah, bahwa akuntansi yang dibentuk ini ditujukan untuk memanusiakan manusia, atau mengembalikan manusia pada fitrahnya yang suci. Sebab menurut penelitian Morgan (1988) diketahui, bahwa praktek akuntansi telah mengakibatkan manusia menjadi less humane. ${ }^{46}$ Atau dengan istilah lain, bahwa masyarakat kita sedang mengalami proses dehumanisasi.

Sifat humanis akuntansi atau bentuk bisnis lainnya tersebut, diharapkan dapat mendorong perilaku manusia itu sendiri.

\footnotetext{
${ }^{44}$ Ibid, 1987, Hal. 10.

${ }^{45}$ Dalam Ibid, 1996, Hal. 11.

${ }^{46}$ Iwan Triyuwono, Op.Cit., 1997, Hal. 13.
} 
Sehingga manusia semakin kuat kesadaran dirinya tentang hakikatnya. Melalui kesadaran diri tentang hakikat manusia ini merupakan landasan bagi manusia dalam memberi nilai emansipatoris pada akuntansi syariah. Sifat ini berarti bahwa tidak lagi berlaku bentuk dominasi atau penindasan dari satu pihak ke pihak yang lain. Dengan kata lain, informasi yang diberikan oleh akuntansi syariah adalah berupa pembebasan dan tertuju pada semua pihak serta tidak menyepelekan pihak lain, atau akuntansi syariah akan berdiri pada posisi yang adil.

Oleh karena akuntansi syariah dibangun berdasarkan syariah Islam, maka nilai transendental akuntansi syariah terlihat jelas. Hal ini merupakan indikasi yang kuat bahwa akuntansi syariah tidak semata-mata menjadi instrumen bisnis yang bersifat profan, tetapi juga sebagai instrumen yang melintas batas dunia profan. Dengan demikian, yang selama ini akuntansi dikenal sebagai alat pertanggungjawaban kepada pemilik perusahaan, maka akuntansi syariah adalah lebih dari itu, yaitu pertanggungjawaban kepada stakeholders dan Tuhan. Dengan sifat ini, dalam melakukan praktek bisnis dan akuntansi maka seseorang yang terlibat akan selalu menggunakan, atau tunduk dan pasrah terhadap kehendak Tuhan (etika syari'ah). Nilai semacam inilah yang dimaksud dengan teologikal. Artinya praktek akuntansi syariah akan mengantarkan pelakunya secara riil teraktualisasi dalam bentuk kegiatan menciptakan dan menyebarkan kesejahteraan bagi seluruh alam.

Mengapa akuntansi syariah muncul ke permukaan, padahal akuntansi Barat telah mengakar dalam inti bisnis masyarakat? Ternyata, para perintis akuntansi, khususnya bidang ekonomi politik akuntansi, memiliki beberapa keraguan tentang pandangan akuntansi modern yang akan menunjukkan data akuntansi secara netral diantara pemakainya. Mereka menganggap hubungan antara akuntansi dan masyarakat adalah penting. Mereka mempertanyakan peranan akuntansi untuk menghubungkan masalahmasalah sosial dengan masalah organisasi dan individual. Sebab perhatian terhadap akuntansi dalam masyarakat tidak sama di mana-mana kendatipun di antara masyarakat (negara-negara) yang menganut konsep itu seluruhnya. $^{47}$

Teori akuntansi harus mengkaji akuntansi di masyarakat dimana ia dipraktekkan. Hal ini berarti bahwa sikap ini mungkin merupakan suatu cara untuk melahirkan aturan-aturan akuntansi. Sebagaimana dijelaskan oleh Gambling, oleh karena tidak adanya aturan akuntansi, maka akuntansi Barat tidak membahas mengenai aturan apa pun yang berkaitan dengan masalah organisasi (perusahaan), yang berhubungan dengan masyarakat dan individu. Aturan semacam itu bisa disebut sebagai suatu bahasan dalam teori akuntansi sekarang. Di pihak lain persyaratan masyarakat mengenai akuntansi secara kuantitatif meningkat juga.

Akuntansi syariah tidak menolak pendapat bahwa akuntansi menyesuaikan kelompokkelompok yang berkepentingan. Tetapi Akuntansi Syariah menyangkut masalah ekonomi, masalah politik, dan juga masalah akuntansi. Dengan kata lain, fungsinya sebagai bagian syariah. Dalam konteks itu harus diterima bahwa akuntansi Islam (syariah) memainkan peranan untuk menyesuaikan kelompok-kelompok yang berkepentingan dalam masyarakat. Secara singkat dapat dijelaskan, bahwa teori akuntansi syariah dipelajari sebagai suatu sistem akuntansi dan pada saat yang sama ditafsirkan sebagai sesuatu yang berhubungan dengan manajemen, ekonomi, hukum, politik, dan agama.

\section{Praktek Akuntansi Syariah}

Kemunculan dan perkembangan lembaga keuangan Islam di Indonesia yang sangat

\footnotetext{
${ }^{47}$ Trevor E. Gambling, "Toward a General Theory of Accounting," International Journal of Accounting Education and Research, Vol. 7, No. 1 (Fall 1971), Hal. 141.
} 
fenomenal, telah memicu lahirnya diskusidiskusi serius lebih lanjut, mulai dari produk atau jasa yang ditawarkan, pola manajemen lembaga, sampai kepada pola akuntansinya. Aspek akuntansi badan usaha memang selalu menarik untuk dijadikan kajian dan bahan diskusi, apalagi bila badan tersebut mempunyai kekhasan tersendiri seperti halnya lembaga keuangan Islam. Menariknya akuntansi untuk dibahas, tentu karena adanya beberapa alasan. Pertama: akuntansi selama ini dikenal sebagai alat komunikasi, atau sering diistilahkan sebagai bahasa bisnis. Kedua, akuntansi sering diperdebatkan apakah ia netral atau tidak. Ketiga, akuntansi sangat dipengaruhi oleh lingkungan (politik, ekonomi, budaya) dimana ia dikembangkan; dan Keempat, akuntansi mempunyai peran sangat penting, karena apa yang dihasilkannya, bisa menjadi sumber atau dasar legitimasi sebuah keputusan penting dan menentukan.

Dengan pertimbangan faktor-faktor di atas, maka manakala lembaga keuangan Islam ramai dibicarakan, timbul pertanyaan seperti, bagaimana dengan akuntansi yang diterapkan oleh lembaga keuangan Islam? Apakah lembaga keuangan Islam boleh memakai akuntansi yang sekarang dikenal, atau harus menerapkan praktik akuntansi yang berbeda? Jika demikian, bagaimana bentuk akuntansi yang lebih Islami, atau dapat diterima syariah? Sejauh mana akuntansi syariah berbeda dengan praktik akuntansi yang sekarang ada?

Pada tatanan teknis operasional, akuntansi syariah adalah instrumen yang digunakan untuk menyediakan informasi akuntansi yang berguna bagi pihak-pihak yang bekepentingan dalam pengambilan keputusan ekonomi. Persoalan yang muncul adalah bagaimana keputusan ekonomi yang sekiranya tidak menyimpang dari syariah Islam atau dapat diterima oleh Islam. Untuk itu, dalam pembahasan teori maupun praktek ekonomi (termasuk di dalamnya bidang manajemen atau akuntansi, misalnya) hendaknya dibahas dari sudut Islam, bukan sekedar dari sudut agama. Dalam kaitan ini, Qardhawi menyarankan, agar: "kita tidak membahas ekonomi dari sudut agama, akan tetapi (membahas) ekonomi dari sudut Islam". ${ }^{48}$ Mengapa demikian? Sebab Islam adalah lebih integral dari sekedar agama. Islam adalah agama dan dunia, ibadah dan muamalah, aqidah dan syariah, kebudayaan dan peradaban, agama dan negara.

Selain dari pada itu, kita mendapatkan hal pokok lain dalam ibadah Islam. Menurut Qardhawi ditegaskan : “... bagian ibadah Islam yang pokok itu, adalah satu ibadah khusus yang istimewa, yang pada kenyataannya merupakan bagian dari sistem keuangan dan ekonomi dalam pandangan Islam. Itulah ibadah zakat, ...Dalam bagian dosa besar yang diharamkan dengan pengharaman yang sangat kuat, kita menemukan dosa besar agama, yang tergolong "tulang belikat" sistem ekonomi bagi sebagian besar umat manusia, baik dahulu maupun sekarang. Itulah riba dimana Rasulullah SAW telah melaknati para pemakannya, pemberinya, penulisnya, dan kedua saksinya..,49

Dengan demikian jelas, bahwa upaya kita menemukan format teori maupun praktek ekonomi (manajemen dan akuntansi Islam) harus dilandaskan pada Islam sebagai sesuatu yang integral. Kemudian diturunkan sampai pada bagian yang lebih bersifat operasional seperti bagaimana pengaturan zakat, bagaimana persoalan riba, dan sebagainya. Hal-hal demikian inilah yang merupakan ciri-ciri khas dari pengembangan bidang/aspek kehidupan yang Islami, sesuai dengan syariah Islam.

Sebagai turunan dari uraian di atas, barangkali uraian tentang keputusan ekonomi yang dihasilkan oleh akuntansi syariah adalah bercirikan sebagai berikut:

\footnotetext{
${ }^{48}$ Yusuf Qardhawi, Loc.Cit., 1997, Hal. 17.
}

IQTISAD Journal of Islamic Economics, Vol. 3, No. 1, Muharram 1423 H/Maret 2002 
Menggunakan nilai etika sebagai dasar bangunan akuntansi, memberikan arah pada, atau menstimulasi timbulnya, perilaku etis, bersikap adil terhadap semua pihak, menyeimbangkan sifat egoistik dengan altruistik, dan mempunyai kepedulian terhadap lingkungan. ${ }^{50}$

Berdasarkan landasan dan ciri-ciri tersebut di atas, maka diharapkan akuntansi syariah akan mempunyai bentuk yang lebih sempurna bila dibandingkan dengan akuntansi konvensional. Sebab melalui ciri-ciri tersebut tercermin sesuatu yang sarat akan pertanggungjawaban, nilai-nilai sosial dan jelas. Mengapa harus demikian? Sebab disadari bahwa pada tatanan yang lebih teknis, yaitu dalam bentuk laporan keuangan, akuntansi syariah masih mencari bentuk. Di dalam tesis ini, bentuk konkrit akuntansi syariah secara utuh belum dapat ditampilkan, sebab untuk sampai pada tataran praktek dan bentuk laporan keuangan yang utuh memerlukan dukungan teori yang lengkap dan kuat.

Di samping itu, usaha membentuk model akuntansi syariah bukan suatu langkah "tambal sulam" yang dilakukan untuk memperbaiki akuntansi konvensional. Akan tetapi, upaya ini harus dilakukan dengan pijakan filosofis yang sangat mendasar. Di balik itu, pemikiran filosofis tidak akan banyak memberikan perubahan, bila tidak dilanjutkan pada pemikiran teoritis dan teknis.

Menurut penilaian Gambling dan Karim, bahwa pendekatan-pendekatan yang digunakan untuk membangun akuntansi (kebanyakan) adalah dengan pendekatan seperti: empiricalinductive approach dan empirical-deductive approach. Di samping itu, Gambling dan Karim mengkritik terhadap metode dan pengukuran akuntansi, serta klasifikasi aktiva. Kritikan dan penilaian Gambling dan Karim tersebut akhirnya ditemukan sebuah

\footnotetext{
${ }^{50}$ Iwan Triyuwono, Op.Cit., 1997, Hal. 19.
}

kesimpulan bahwa untuk pengukuran zakat dari harta dan aset yang dimiliki oleh perseorangan maupun perusahaan, harus digunakan pendekatan lain. ${ }^{51}$

Akuntansi Syariah sebagai Refleksi Akuntansi Sosial dan Pertanggungjawaban. Wujud akuntansi syariah tercermin dalam kiasan atau metafora "amanah". Metafora amanah dapat diturunkan menjadi metafora "zakat", atau dengan kata lain, realitas organisasi akuntansi syariah adalah realitas organisasi yang dimetaforakan dengan zakat. Metafora ini membawa konsekuensi pada organisasi bisnis, yaitu organisasi bisnis yang tidak lagi berorientasi pada laba (profitoriented) atau berorientasi pada pemegang saham (stakeholders-oriented), tetapi berorientasi pada zakat (zakat-oriented). ${ }^{52}$ Dengan orientasi zakat, perusahaan berusaha untuk mencapai "angka",53 pembayaran zakat yang tinggi. Dengan demikian, laba bersih (net profit) tidak lagi menjadi ukuran kinerja (performance) perusahaan, tetapi sebaliknya zakat menjadi ukuran kinerja perusahaan.

Dilihat dari nilai praktis akuntansi, akuntansi syariah dengan metafora amanah dan berorientasikan zakat merupakan metafora akuntansi yang sangat fokus pada orientasi sosial dan pertanggungjawaban. Sebab akuntansi (bisnis) yang bermetaforakan amanah biasanya memiliki nilai praktis yang bersifat humanis, emansipatoris, transendental $^{54}$ dan teleologikal. $^{55}$ Nilai praktis ini, menunjukkan sifat amanah bagi para pelaku

\footnotetext{
${ }^{51}$ Pengukuran zakat akan diuraikan pada sub bab Penilaian-penilaian Perhitungan (Pengukuran) Zakat dalam Akuntansi.

${ }^{52}$ Triyuwono, "Akuntansi Syariah: Implementasi Nilai Keadilan dalam Format Metafora Amanah", Kertas Kerja, Disampaikan dalam Kuliah Umum di Fakultas Syariah IAIN Walisongo Surakarta, 24 Februari 1997. Hal. 13.

${ }^{53}$ Pengertian angka dan zakat di sini tidak perlu diartikan secara sempit, karena zakat-oriented itu sendiri adalah metafora yang mempunyai makna dan konsekuensi yang luas dan komprehensif.

${ }^{54}$ Kuntowidjojo, Paradigma Islam: Interpretasi untuk Aksi, Bandung : Penerbit Mizan

${ }^{55}$ Triyuwono, Ibid, hal. 13.
} 
dan penggunanya. Menurut tradisi Islam, sebagaimana yang pernah diuraikan di muka, sifat amanah dapat diturunkan menjadi ciri khas zakat. Dengan demikian, zakat merupakan tujuan akhir dari setiap unit bisnis Islami (syariah).

Nilai praktis akuntansi syariah yang berorientasi zakat tersebut, menimbulkan konsekuensi ontologis, bahwa akuntan secara kritis harus mampu membebaskan manusia dari ikatan realitas (peradaban) manusia beserta jaringan-jaringan kuasanya, untuk kemudian memberikan atau menciptakan realitas alternatif dengan seperangkat jaringanjaringan kuasa Ilahi yang mengikat manusia dalam hidup sehari-hari. Dengan istilah lain, dapat terbangunnya ontologi tauhid. Dengan cara demikian, realitas alternatif diharapkan akan dapat membangkitkan kesadaran diri secara penuh akan kepatuhan dan ketundukan seseorang pada kuasa Ilahi. Melalui kesadaran diri ini, seseorang akan selalu merasa kehadiran Tuhan dalam dimensi waktu dan tempat di mana berada.

Jadi, dengan akuntansi syariah, realitas sosial yang dikonstruk mengandung nilai tauhid dan ketundukan pada jaringan-jaringan kuasa Ilahi; yang semuanya dilakukan dengan meta-perspective, yaitu perspektif khalifat-ulLah fil ardh, suatu cara pandang yang sadar akan hakikat diri manusia dan tanggungjawab kelak di kemudian hari di hadapan Allah SWT. Dalam skala mikro, realitas sosial dapat diidentikan dengan realitas organisasi, yaitu realitas yang diciptakan dalam organisasi bisnis, sehingga terbentuk kondisi seperti yang dicitakan dalam ontologi tauhid tadi. Bila realitas organisasi yang demikian tercipta, maka sangat mungkin bahwa realitas tersebut akan menebarkan rahmat, yang tidak saja bagi mereka yang secara aktif terlibat dalam operasi organisasi, tetapi juga kepada masyarakat luas dan lingkungan alam sekitarnya.
Gambaran ideal tersebut di atas dapat diwujudkan bila organisai (bisnis) dikiaskan sebagai zakat. Penggunaan kiasan semacam ini adalah sangat penting, karena dengan cara ini seseorang akan merancang organisasi. Sebagaimana diketahui, bahwa banyak metafora-metafora organisasi yang telah dikenal, diantaranya: cybernetic system, population ecology, political system, theater, culture dan lain-lainnya. ${ }^{56}$ Kesemua metafora ini berdiri di atas paradigma positivistik. Penggunaan masing-masing metafora tersebut mempunyai implikasi sendiri-sendiri terhadap realitas kehidupan manusia. Penggunaan metafora amanah dan zakat dalam bentuk yang lebih operasional merupakan salah satu alternatif untuk menciptakan realitas organisasi yang terikat pada jaringan-jaringan kuasa Ilahi. Dengan demikian, bila metafora zakat (realitas organisasi bermetaforakan zakat) secara sadar diterima dan dipraktikkan dalam kegiatan bisnis sebuah perusahaan atau dalam keseluruhan sistem bisnis, maka di dalamnya akan tercipta apa yang dinamakan dengan realitas organisasi dengan jaringan kuasa Ilahi. Realitas organisasi demikian inilah yang harus direfleksikan secara "obyektif" oleh akuntansi. Oleh karena, dengan "obyektivitas", akuntansi tidak akan membiaskan atau mendistorsikan realitas organisasi yang bermetaforakan zakat ke dalam bentuk realitas lainnya.

Islam adalah agama yang rahmatan lil 'alamiin. Artinya ajaran Islam akan dapat diterapkan atau dipakai siapa saja, dan dimana saja. Rahmatan lil 'alamiin adalah sebuah konsep yang mengandalkan pada konsep keadilan. Keadilan merupakan isi kandungan yang tidak dapat dihilangkan dari keyakinan Islam. Sehingga kondisi ideal masyarakat Islam tidak akan dapat tercapai apabila keadilan tidak ditegakkan. Islam ingin menjinakkan semua perilaku dzalim dari masyarakat. Termasuk di dalamnya adalah

\footnotetext{
${ }^{56}$ Ibid, hal. 16.
}

IQTISAD Journal of Islamic Economics, Vol. 3, No. 1, Muharram 1423 H/Maret 2002 
perilaku dzalim masyarakat bisnis. Perilaku dzalim adalah perilaku-perilaku dalam bentuk diskriminasi, ketidakadilan, eksploitasi, tekanan dan perilaku sewanang-wenang yang dengan dengan perilaku ini dapat merugikan orang lain.

Pertanyaan mendasar yang muncul adalah kapan suatu keadilan dalam suatu masyarakat terwujud? Keadilan masyarakat merupakan keadilan ideal, dimana masyarakatnya dapat hidup dengan layak dalam berbagai bidang. Tidaklah mungkin untuk mendapatkan masyarakat Islam yang ideal sementara keadilan tidak ditegakkan.

Berdasarkan paparan di atas, satu hal yang tidak dapat dihindari dari keyakinan Islam bahwa manusia merupakan khalifah (wakil) Tuhan, dan manusia harus mengatur hidup sesuai dengan status mereka. Pengarahan-pengarahan yang terkandung dalam ajaran-ajaran Islam adalah dalam rangka membantu merealisasikan tujuan ini. Para ulama sangat percaya bahwa kesejahteraan umat dan peringanan mereka dari beban hidup yang berat merupakan tujuan dasar syariah. Pandangan ini, jika dilihat dari sudut pandang ekonomi merupakan penekanan pada penciptaan kelayakan ekonomi melalui pemenuhan kebutuhan dasar dan penciptaan keadilan sosial-ekonomi.

Dari sinilah diperlukan suatu penanganan dan pendekatan serta studi yang berorientasi sosial, sehingga seluruh fungsi perusahaan harus berlandaskan pada nuansa Islami. Sebagai contoh misalnya pada bidang akuntansi. Hal penting untuk dicatat, bahwa perbedaan dalam struktur sosial mempengaruhi pengembangan bidang dalam suatu masyarakat tertentu. Demikian pula pengaruhnya pada bidang akuntansi. Dengan kata lain, akuntansi adalah refleksi budaya. Demikian pula kuntansi Islam (syariah) pada dasarnya adalah refleksi budaya Islam.

Pembicaraan mengenai akuntansi Islam haruslah dipahami sebagai sebuah alat yang memiliki orientasi sosial. Mengapa demikian?
Sebab akuntansi Islam tidak hanya sebagai alat untuk menterjemahkan fenomena ekonomi dalam bentuk ukuran moneter tetapi juga sebagai suatu metode untuk menjelaskan bagaimana fenomena ekonomi itu berjalan dalam masyarakat Islam. Hal ini tidak sama dengan perbedaan antara akuntansi deskriptif dengan akuntansi normatif. Akuntansi deskriptif ini bertujuan untuk menawarkan akuntansi yang cocok dengan tujuan tertentu. Jika tujuan berbeda, maka pasti norma juga berbeda.

Akuntansi Islam memiliki satu tujuan yaitu akuntansi harus mematuhi prinsip Islam. Akuntansi Islam muncul sebagai turunan dari prinsip-prinsip Islam. Dalam kaitan ini, semua akuntansi Islam dapat disebut normatif. Tetapi, benar juga jika disebut bahwa di mata masyarakat (Islam), perbedaan yang menarik antara positif-normatif atau deskriptif/preskriptif atau dikotomi mendasar antara fakta-nilai yang merupakan sifat yang dianut, merupakan suatu jenis pengetahuan yang saat ini terjebak dalam suasana kendala metodologi dalam studi akuntansi khususnya tentang Akuntansi Islam. Hukum Islam atau syariah, berlaku bagi setiap muslim dan membentuk aturan dasar bagi semua lembaga keuangan syariah (Islam), termasuk perbankan syariah. Syariah diterapkan untuk mewujudkan masyarakat ideal, sehingga lembaga keuangannya dan akuntansi memiliki kesamaan pembenarannya sendiri. Tentu saja ada perbedaan pendapat terhadap suatu fenomena ekonomi. Argumen mengenai sifat-sifat zakat misalnya. Tidak peduli apakah perusahaan menghemat uang atau pemerintah mengumpulkan zakat, tetapi masalahnya adalah menentukan apakah yang terbaik untuk memahami Islam.

Secara jelas akuntansi Islam yang diterapkan pada lembaga keuangan syariah adalah upaya penerapan akuntansi yang menyangkut masalah ekonomi, masalah politik, dan juga masalah akuntansi itu sendiri. Dengan kata lain, fungsinya sebagai bagian dari syariah. Dalam konteks itu harus 
diterima, bahwa akuntansi syariah memainkan peranan untuk menyesuaikan kelompokkelompok yang berkepentingan bisnis dalam masyarakat. Di sinilah letak posisi sosial dari akuntansi Islam.

Akuntansi berorientasi sosial adalah sebuah akuntansi yang menyajikan atau mengungkap dampak sosial perusahaan terhadap masyarakat. ${ }^{57}$ Dengan demikian, pengungkapan perusahaan tentang dampak sosialnya terhadap masyarakat sebagai suatu kewajiban. Jika ihwalnya adalah berkaitan dengan masalah kewajiban sosial, maka cara baku untuk pengembangan akuntansi yang dapat diterima oleh seluruh umat -sesuai dengan sifat rahmatan lil 'alamiin ajaran Islam- adalah dengan cara memperluas konsep dasar sistem zakat.

Mengapa harus memperluas konsep dasar sistem zakat? Sebab sebagaimana diuraikan pada bagian sebelumnya, bahwa zakat sebagai suatu institusi yang memiliki perspektif sosial harus dikenakan kepada seluruh aktiva perusahaan maupun perorangan. Walaupun meski harus dilihat lebih dahulu apakah zakat dikenakan kepada aktiva lancar atau tidak lancar. Mengingat zakat merupakan pengeluaran yang harus dibayarkan setelah mencapai nishab. Nishab terjadi apabila harta yang dimiliki seseorang atau perusahaan itu bertambah dan bertambah, sehingga yang bersangkutan akan dikenai pengeluaran zakat apakah sebanyak 2,5\%, 5\% atau $10 \%$, tergantung pada jenis aktiva yang menghasilkan yang dimiliki oleh seseorang atau perusahaan. Dengan kata lain, zakat dalam akuntansi dikenakan pada aktiva lancar.

Oleh karena orientasi sosial akuntansi syariah adalah dibebankan kepada perluasan konsep zakat, maka kias (metafora) organisasi akuntansi harus dirujukkan pada orientasi zakat, bukan lagi pada orientasi laba atau

${ }^{57}$ Trevor Gambling dan R.A.A. Karim, Loc.Cit. 1986, Hal. 214. stakeholder oriented. $^{58}$ Inilah yang lebih lanjut dikatakan oleh Triyuwono sebagai organisasi bermetaforakan "amanah". Orientasi zakat mengandung pengertian luas dan komprehensif. Sebab zakat bukan sekedar dinyatakan dalam bentuk angka-angka prosentase, akan tetapi melalui zakat dapat diketahui kinerja perusahaan. Yaitu semakin tinggi zakat yang dikeluarkan oleh perusahaan berarti semakin besar laba yang di dapat perusahaan.

Lebih tegas lagi dapat dikatakan, bahwa penggunaan kiasan (metafora) zakat untuk menciptakan realitas organisasi mempunyai beberapa makna. Menurut Triyuwono ada lima makna realitas organisasi tersebut, yaitu: ${ }^{59}$

- Ada transformasi dari pencapaian laba bersih (yang maksimal) ke pencapaian zakat.

- Karena yang menjadi tujuan adalah zakat, maka segala bentuk operasi perusahaan (akuntansi) harus tunduk pada aturan main (rules of game) yang ditetapkan dalam syariah.

- Zakat mengandung perpaduan karakter kemanusiaan yang seimbang antara karakter egoistik dan altruistik/sosial.

- Zakat mengandung nilai emansipatoris.

- Zakat adalah jembatan penghubung antara aktivitas manusia yang bersifat duniawi dan ukhrowi.

Apabila dianalisis lebih lanjut, pemikiran di atas jelas menunjukkan orientasi sosial yang jelas dari zakat. Pada saat zakat ditempatkan sebagai metofora organisasi atau zakat sebagai inti organisasi akuntansi. Sebagaimana makna pertama: ada transformasi dari pencapaian laba bersih (yang maksimal) ke pencapaian zakat. Hal ini berarti bahwa pencapaian laba bukan merupakan tujuan akhir perusahaan, tetapi hanya sekedar tujuan antara.

\footnotetext{
${ }^{58}$ Iwan Triyuwono, Loc.Cit. 1997, Hal. 13.

${ }^{59}$ Ibid. Hal. 13-14.
} 
Oleh karena zakat menjadi tujuan akhir, maka segala bentuk operasi perusahaan (akuntansi) harus tunduk pada aturan main (rules of game) yang ditetapkan dalam syariah. Sebagai contoh: kapan seseorang atau perusahaan mengeluarkan zakat sebagai orientasi sosial perusahaan; berapa persen zakat yang dikeluarkan oleh seseorang atau perusahaan; dan siapa saja yang harus diberi zakat. Kesemuanya ini dijalankan mengikuti aturan-aturan main yang ada dalam syariah Islam. Penyimpangan terhadap aturan atau hukum syariah menjadikan tidak sahnya tujuan zakat.

Zakat mengandung perpaduan karakter kemanusiaan yang seimbang antara karakter egoistik dan altruistik/sosial. Artinya, bahwa seseorang mengeluarkan zakat berarti ia telah mementingkan lebih dahulu kepentingan orang lain daripada kepentingan pribadinya. Karakter egoistik mencerminkan bahwa seseorang atau perusahaan tetap diperkenankan untuk mencari laba (namun tetap dalam bingkai Syariah), dan kemudian sebagian dari laba (dan kekayaan bersih) yang diperoleh dialokasikan sebagai zakat. Sedangkan altruistik atau sosial mempunyai arti bahwa perusahaan juga mempunyai kepedulian yang sangat tinggi terhadap kesejahteraan manusia dan alam lingkungan yang semuanya ini tercermin dalam zakat itu sendiri.

Zakat mengandung nilai emansipatoris. Hal ini berarti, bahwa zakat sebagai lambang pembebas manusia dari ketertindasan ekonomi, sosial, dan intelektual, serta pembebasan alam dari penindasan dan eksploitasi manusia. Akhirnya, zakat adalah jembatan penghubung antara aktivitas manusia yang bersifat duniawi dan ukhrowi. Hal ini berarti, bahwa zakat sebagai jembatan, memberikan kesadaran ontologis bagi diri manusia, karena segala bentuk kegiatan profan selalu berkait erat dengan kehidupan manusia dihadapan Allah kelak di akhirat.
Dengan demikian jelas, bahwa kiasan (metafora) akuntansi syariah harus dibangun dengan memperhatikan makna zakat, sebagai suatu orientasi sosial. Sebab orientasi ini akan berkaitan erat dengan tujuan akhir kinerja akuntansi. Tujuan akhir kinerja akuntansi adalah pembuatan laporan sebagai bahan pertanggungjawaban tentang kondisi aktiva, pasiva, dan modal yang dimiliki oleh seseorang maupun perusahaan.

Implikasi dari pemikiran di atas menunjukkan, bahwa semua perangkat organisasi yang akan disusun harus benarbenar merefleksikan zakat sebagai suatu kias (metafora). Hal ini menunjukkan adanya bentuk transformasi. Transformasi ini tidak saja akan mempengaruhi perilaku manajemen, stockholders, karyawan, dan masyarakat sekelilingnya, tetapi juga perangkat informasi. Perangkat informasi yang ada dalam perusahaan inilah yang biasanya berbentuk akuntansi yang digunakan oleh organisasi yang bersangkutan.

Kecuali itu harus diingat, bahwa bentuk organisasi digambarkan di atas bukanlah sebagai satu-satunya faktor yang berpengaruh terhadap kias (metafora) dan orientasi akuntansi syariah. Akan tetapi, faktor-faktor lain seperti sistem ekonomi, sosial, politik, peraturan perundang-undangan, kultur, persepsi, dan nilai yang berlaku dalam masyarakat, mempunyai tanggungjawab yang besar terhadap bentuk akuntansi. Hal inilah yang menunjukkan bahwa akuntansi merupakan keutuhan (entitas) informasi yang tidak bebas nilai, tetapi merupakan keutuhan (entitas) informasi yang sarat nilai.

Satu hal penting yang dapat dikaji dari ayat 282 surat al-Baqarah adalah adanya perintah dari Allah kepada kita untuk menjaga: Keadilan dan Kebenaran di dalam melakukan setiap transaksi. Lebih dalam perintah ini menekankan pada kepentingan pertanggungjawaban (accountability) agar pihak yang terlibat dalam transaksi itu tidak dirugikan, tidak menimbulkan konflik, dan 
adil. Untuk mewujudkan sasaran ini maka dalam suatu transaksi diperlukan saksi.

Di samping itu, kalau kita kembali kepada pembahasan, bahwa manusia diciptakan Allah di muka bumi ini memiliki fungsi dan peran ganda, yaitu: fungsi khalifah dan abdullah (wakil dan hamba). Di dalam menjalankan fungsi dan peran ini tentu saja pemberi peran akan meminta pertanggungjawaban atas pelaksanaan fungsi tersebut. Oleh karena itu, di dalam akuntansi kehidupan manusia, maka manusia sebagai khalifah dan abdullah tersebut tidak dapat dilepaskan dari proses akuntansi. Dengan kata lain, manusia akan selalu mempertanggungjawabkan seluruh perbuatan dan amalnya dihadapan Sang pemberi amanah, yaitu Allah SWT.

Gambaran di atas harus dijadikan pijakan dalam pengembangan format akuntansi syariah, yang berdimensikan pertanggungjawaban (accountability). Dimensi pertanggungjawaban dalam akuntansi syariah adalah memiliki cakupan yang luas. Jadi pertanggungjawaban ini bukan hanya pertanggungjawaban atas uang (finansial) yang digunakan dalam melaksanakan kegiatan, akan tetapi pertanggungjawaban ini harus mampu meningkatkan tanggungjawab secara horizontal dan vertikal. Pertanggungjawaban horizontal tertuju pada masyarakat, pemerintah dan kepatuhan pada peraturan. Sementara pertanggungjawaban vertikal adalah tertuju pada transendensi aktivitas (finansial, dan sebagainya) kepada Dzat yang memberikan tanggungjawab. Secara rinci, pertanggungjawaban akuntansi dimaksudkan untuk memenuhi informasi dalam rangka pemenuhan kebutuhan. Sehubungan dengan kepentingan-kepentingan tersebut Hadjisarosa mengidentifikasi sebagai berikut:

- Kelangsungan hidup dan perkembangan perusahaan

- Pelanggan

- Pemilik modal

- Karyawan

- Rekanan
- Pemerintah

- Masyarakat, dan

- Pelestarian lingkungan. ${ }^{60}$

Kendatipun telah terdapat delapan kepentingan yang harus diperhatikan dalam melakukan pertanggungjawaban atas kondisi dan informasi akuntansi, namun delapan hal tersebut hanyalah baru sebatas pada dimensi horizontal. Timbul pertanyaan, dimanakah letak dimensi vertikalnya? Jawabanya adalah ada pada dimensi zakat. Zakat sebagai manifestasi pertanggungjawaban hamba yang melakukan perbuatan/aktivitas bisnis yang dapat diaudit kemudian dipertanggungjawabkan kesucian modal kepada Dzat pemberi modal. Dimensi inilah yang merupakan dimensi paling tinggi.

Perihal yang berkaitan dengan masalah pertanggungjawaban secara vertikal secara syariah diatur oleh hukum-hukum Allah yang terdapat dalam al-Qur'an dan sunnah Rasul. Persoalan berikutnya adalah bagaimana upaya untuk meningkatkan accountability yang berkaitan dengan dimensi horizontal. Kiranya pandangan Lee Parker dapat dijadikan rujukan atau petunjuk bagi peningkatan accountability, sebagai berikut :

- Mengintegrasikan antara data keuangan dan nonkeuangan

- Penilaian terhadap hasil yang bersifat keuangan dan non keuangan dengan membandingkannya dengan tujuan yang ingin dicapai.

- Memperluas ruang lingkup tanggung jawab mencakup masyarakat/lingkungan

- Laporan menyangkut tingkat kepatuhan perusahaan pada peraturan pemerintah dan standar akuntansi. ${ }^{61}$

Dalam kerangka inilah, maka para akuntan dihadapkan pada kemajuan masa depan, yang penuh dengan ketidakpastian,

\footnotetext{
${ }^{60}$ Poernomosidi Hadjisarosa, Loc.Cit. 1997, Hal. 48-49.

${ }^{61}$ Lee D. Parker,. Here's to An Accountable Future. (Australia: International Accounting Conference), November 14-16, 1994. Hal. 163.
} 
ketidak beresan. Ketika kondisi ini terjadi, maka para akuntan harus menghormati nilai, norma dan etika teologis. Sehingga mereka mampu menampilkan dirinya sebagai akuntan yang dapat dipercaya, jujur, bertanggungjawab, dan sebagainya. Dengan demikian, akuntansi masa depan mestinya bukan hanya berorientasi pada pengambilan keputusan (decision making oriented) akan tetapi harus berorientasi pada pertanggungjawaban (accountability oriented).

Sesuai dengan kata kunci pembicaraan ini, yaitu pertanggungjawaban, maka akuntansi pertanggungjawaban merupakan ciri khas akuntansi syariah. Sebab akuntansi pertanggungjawaban adalah akuntansi yang memberikan informasi yang adil dan bernar. Dengan demikian akuntansi syariah (Islam) yang memiliki unsur pengertian ekonomi, politik, dan agama memiliki kemungkinan besar untuk menunjukkan kunci ke arah akuntansi Pasca Newton. ${ }^{62}$

Berdasarkan pembahasan ini, maka secara nyata menunjukkan bahwa akuntansi syariah (Islam) dapat memberikan sumbangan untuk menciptakan paradigma baru dalam akuntansi. Namun perlu ketegasan, bahwa tidak perlu lagi untuk membedakan antara Akuntansi normatif dan deskriptif dalam akuntansi Islam. Sebab di dalam Islam keduanya akan berjalan. Tidak mungkin ditemukan deskripsi jika tidak ada norma. Norma adalah acuan dalam pengembangan deskripsi. Jadi keduanya ibarat koin mata uang, yang memiliki sisi berbeda namun nilainya sama.

\section{KESIMPULAN}

Berdasarkan paparan di atas dapat disimpulkan hal-hal sebagai berikut:

Pada tataran praktis akuntansi syariah adalah akuntansi yang berorientasi sosial dan pertanggungjawaban. Sebab akuntansi syariah dapat menyajikan atau mengungkap dampak

\footnotetext{
${ }^{62}$ Toshikabu Hayashi, On Islamic Accounting, (Tokyo: Institute of Middle Eastern Studies, International University of Japan), 1995, Hal. 163.
}

sosial perusahaan terhadap masyarakat dan sekaligus menyajikan laporan pertanggungjawaban yang bersifat humanis, emansipatoris, transendental dan teologikal. Oleh karena itu, konsep dasar akuntansi syariah adalah bersifat zakat dan amanah oriented.

Perkembangan lebih lanjut akuntansi bukan sekedar dianggap sebagai ilmu (science) dan teknologi universal yang bebas nilai. Akan tetapi, akuntansi adalah produk sejarah yang merefleksikan budaya di tempat akuntansi dilaksanakan. Dengan kata lain, akuntansi syariah adalah ilmu dan teknologi universal yang tumbuh dan berkembang sesuai dengan perubahan yang terjadi di dalam lingkungannya, baik sosial, ekonomi, politik, peraturan perundangan, kultur, persepsi dan nilai (masyarakat) tempat akuntansi syariah diterapkan.

Akuntansi syariah adalah akuntansi yang dikembangkan bukan hanya dengan cara "tambal sulam" terhadap akuntansi konvensional, akan tetapi, merupakan pengembangan filosofis terhadap nilai-nilai al-Qur'an yang diturunkan ke dalam pemikiran teoritis dan teknis akuntansi. Oleh karena itu, secara substantif akuntansi syariah bersifat humanis, emansipatoris, transendental dan teologikal.

\section{DAFTAR PUSTAKA}

Adnan, M. Akhyar (1996). “(Teknologi) Akuntansi Syariah", Kertas Kerja Seminar Nasional Hari Teknologi Nasional, Yogyakarta.

Alvesson, M., (1987). Organization Theory and Technocrative Consciousness: Rationality, Ideology and Quality of Work. New York: De Gruyter.

As-Sadr, M. Baqir. (1986). Islamic Economic. Translated: Toshio Kuroda (Isuramu Keizaron). Neigata: The Institute of Middle Easter Studies, International University of Japan.

Baswir, Revrisond. (1996). Akuntansi dan Ideologi, Kertas Kerja pada Seminar 
Nasional Harteknas, Yogyakarta 27 Desember.

Chastain, Clark E. (1993). Accounting and Society: A Behavioral View, International Journal of Accounting, Education and Research, Vol. 8, No. 2 Spring .

Claughlin, R., (1987). Accounting System in Organization Theory: A Case for Critical Theory, Accounting, Organization and Society.

Cooper, D.J. dan T.M. Hopper, (1987). Critical Studies in Accounting, Accounting Organization and Society. New York: Prentice-Hall International, Inc.

Gaffikin, M.J.R. (1998). Accounting Methodology and The Work of R.J. Chambers. New York: Garland Publishing, Inc.

Gambling, Trevor E. (1971). Toward a General Theory of Accounting. International Journal of Accounting Education and Research, Vol. 7, No. 1 Fall.

Gilling, D.M. (1996). Accounting and Social Change, International Journal of Accounting, Education and Research, Vol. 1, No.2 Spring.

Hadjisarosa, Poernomosidi, (1997), Makalah Kursus Singkat dan Lokakarya Ekonomi Islam II Sekolah Tinggi Ilmu Syari'ah, Yogyakarta, tanggal 18 - 21 Agustus, Hal. 4.

Harahap, Sofyan Syafri, (1997). Akuntansi Islam, Jakarta: Bumi Aksara,

Hayashi, Toshikabu. (1995). On Islamic Accounting, Tokyo: Institute of Middle Eastern Studies, International University of Japan.

Kuntowidjojo, Paradigma Islam: Interpretasi untuk Aksi, Bandung: Penerbit Mizan,

Laughlin, R.C., T. et. al. (1989). Contextual Studies of Accounting and Auditing: An Introduction, Accounting, Auditing and Accountability. Journal.
Laszlo, Ervin. (1971). Introduction to System Philosophy. New York: Sciece Publishers, Inc.

Lodh, Sudhir C. (1996). Critical Studies in Accounting Research, Rationality and Habermas: A Methodological Reflection, Paper to be Presented at the Fourth CPA Conference. New York City, 26-28 April

MacIntosh, N.B. (1988). Deconstructionism and Critical Accounting. Paper Presented at The Second Interdiciplinary Perspectives on Accounting Conference at the University of Manchester July.

Neimark, M. and Tinker, (1996). The Social Construction of Management Control System. New York: Prentice-Hall.

Parker, Lee D. (1994). Here's to An Accountable Future. Australia: International Accounting Conference, November 14-16.

Runes, Dagobert D. (1976). Dictionary of Philosophy. New Jersey: Littlefield, Adams \& Co.

Shahata, Shauqi Ismail. (1987). Financial Accounting from the Islamic Point of View, Cairo: Alzahra al-A'lam alA'rabi, Hal. 9.

Triyuwono, Iwan (1996). Organisasi, Akuntansi, dan Spiritualisme Islam, Makalah Stadium General Mahasiswa Syari'ah Banking Institute Yoyakarta, tanggal 28 September, (19970 Akuntansi Syariah: Implementasi Nilai Keadilan dalam Format Metafora Amanah, Kertas Kerja, Disampaikan dalam Kuliah Umum di Fakultas Syariah IAIN Walisongo Surakarta, 24 Februari.

M.J.R. Gaffikin, (1996), Shari'ate Accounting: An Ethical Construction of Accounting Knowledge The Fourth Critical Perspectives on Accounting Symposium, 26-28 April 1996, New York City, 